\title{
Synthesis, Characterization and Antimicrobial Study of Mannich Base Derived from Piperidine and its Metal Complexes
}

\author{
Amol G. Kadlag*
}

Department of Chemistry, S. N. Arts, D. J. M. Commerce and B. N. S. Science College, Sangamner, Dist.Ahmednagar, Maharashtra, India

\section{Article Info}

Volume 7, Issue 4

Page Number: 191-195

Publication Issue :

July-August-2020

\section{Article History}

Accepted : 10 Aug 2020

Published : 16 Aug 2020

\section{ABSTRACT}

A ligand derived from piperidine, thiourea and benzaldehyde and its metal complexes with $\mathrm{Co}(\mathrm{II}), \mathrm{Ni}(\mathrm{II}), \mathrm{Zn}(\mathrm{II})$ and $\mathrm{Mn}(\mathrm{II})$ have been synthesized and characterized by IR and thermogravimetry. The antimicrobial activities of the ligand and its metal complexes were determined against the bacteria Escherichia coli.

Keywords: Transition metal complex, piperidine, thiourea, benzaldehyde, antimicrobial activity

\section{INTRODUCTION}

Metal complexes ${ }^{1}$ of Mannich bases have been studied extensively in recent years due to the selectivity and sensitivity of ligand towards various biological important metal ions. Mannich reaction is a three component condensation reaction consisting of active hydrogen containing compound. ${ }^{2,3}$ Mannich base complexes have remained an important and popular are of research due to their simple synthesis adaptability and divers range of applications. Metal complexes of Mannich bases played a vital role in the development of coordination chemistry. Mannich bases of piperidine exhibits various pharmacological activities $^{4}$ like antimicrobial, ${ }^{5}$ analgesic, ${ }^{6}$ antiinflammatory, ${ }^{7}$ antiviral, ${ }^{8}$ anticancer, ${ }^{9}$ etc. Organic chelating ligands containing amide moiety as a functional group have a strong ability to form metal complexes and exhibit a wide range of biological activity. ${ }^{10}$

Heterocyclic moieties are shows wide range of biological activities. The structural diversity and biological importance of nitrogen containing heterocyclic moieties have made them attractive synthetic targets. ${ }^{11-15}$

Thiourea derivatives are selective reagents especially for the determination of transition metal ion complexes. Thiourea have a long history of being used as a ligand in coordination chemistry and to coordinate with a metal via $\mathrm{S}$ and $\mathrm{N}$ atoms. ${ }^{16-18}$

The present paper describes the preparation of Mannich base using thiourea. This work deals with the condensation reaction of thiourea, piperidine and benzaldehyde. ${ }^{19}$ The sulphur atom of thiourea along 
with the nitrogen of piperidine moiety expected to make it a good ligand for complex formation with transition metals. Thiourea ligands contain the sulphur as well as nitrogen atoms have ability to form the metal complexes.

\section{METHODS AND MATERIAL}

All the chemicals and solvents were of the highest purity and were used as received. IR spectra were recorded with $\mathrm{KBr}$ pellets using FT-IR Shimadzu instrument.

Synthesis of Mannich base (BNH): To the metanolic solution of thiourea $(1),(0.761 \mathrm{~g}, 0.01 \mathrm{~mol})$, piperidine (2), (0.852 g, $0.01 \mathrm{~mol})$ was added followed by benzaldehyde (3), (1 mL, $0.01 \mathrm{~mol})$. The reaction mixture was then refluxed with constant stirring at 60 $-70{ }^{\circ} \mathrm{C}$ for about $4 \mathrm{~h}$. The colourless solid formed was filtered and washed with methanol. The crude solid obtained was dried and recrystallized using methanol.<smiles>NC(N)=S</smiles>

1<smiles>C1CCNCC1</smiles>

2<smiles>O=Cc1ccccc1</smiles>

3

Synthesis of metal complexes: To a hot magnetically stirred methanolic solution of Mannich base $(0.1 \mathrm{~mol})$, the methanolic solution of metal(II) salt $(0.05 \mathrm{~mol})$ was added. The mixture was then refluxed about $1 \mathrm{~h}$. The complex was precipitated, then filtered, washed with methanol then dried and cooled in a desicator.
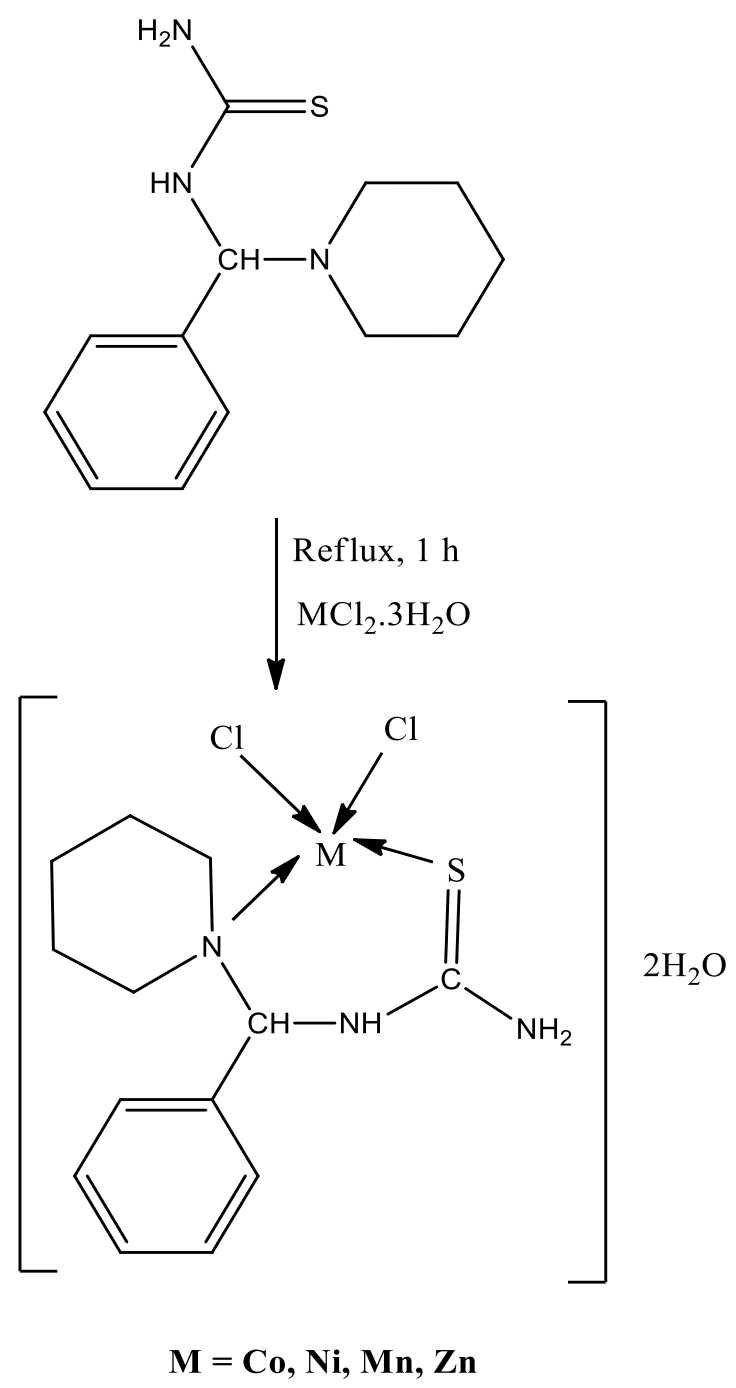

Scheme-II: Synthesis of Metal complex

\section{RESULTS AND DISCUSSION}

The IR spectra of the complexes indicates that ligand behaves as a bidentate. In the ligand, the band appearing at $1618 \mathrm{~cm}^{-1}$ due to $\mathrm{C}=\mathrm{S}$ stretching is shifted to lower side at $1557-1610 \mathrm{~cm}^{-1}$ in the complexes by 
confirming the coordination through the sulphur atom of thiourea and not through nitrogen atom.

Similarly, in the ligand, the band appearing at 1209$1080 \mathrm{~cm}^{-1}$ due to $\mathrm{C}-\mathrm{N}$ stretching of piperidine is shifted to lower side at $1037-1070 \mathrm{~cm}^{-1}$ in the complexes by confirming the coordination through the tertiary nitrogen atom of piperidine ring. (Table$1)$.

Table -1 : IR stretching frequencies of ligand and its metal complexes

\begin{tabular}{|c|c|c|c|c|}
\hline \multicolumn{5}{|c|}{ Table -1} \\
\hline Compound & $v(\mathrm{C}=\mathrm{S}) \mathrm{cm}^{-1}$ & $\begin{array}{c}v(\mathrm{C}-\mathrm{N}) \mathrm{cm}^{-1} \\
\text { of piperidine }\end{array}$ & $\begin{array}{c}v\left(\mathrm{CH}_{2}\right) \mathrm{cm}^{-1} \\
\text { of piperidine }\end{array}$ & $v(\mathrm{M}-\mathrm{N}) \mathrm{cm}^{-1}$ \\
\hline BNH (Ligand) & 1618 & $1209-1080$ & 2945 & -- \\
\hline Co- BNH & 1557 & 1070 & 2866 & 445 \\
\hline Ni- BNH & 1602 & 1043 & 2820 & 524 \\
\hline Mn- BNH & 1564 & 1053 & 2831 & 515 \\
\hline Zn- BNH & 1610 & 1037 & 2850 & 455 \\
\hline
\end{tabular}

Thermogravimetric Analysis (TGA): All the metal complexes were analyzed by dynamic thermogravimetry. In TGA we measure weight loss with respect to temperature. The TG curve suggested that weight loss corresponds for water molecules and temperature range indicates that the nature of water molecule is lattice.

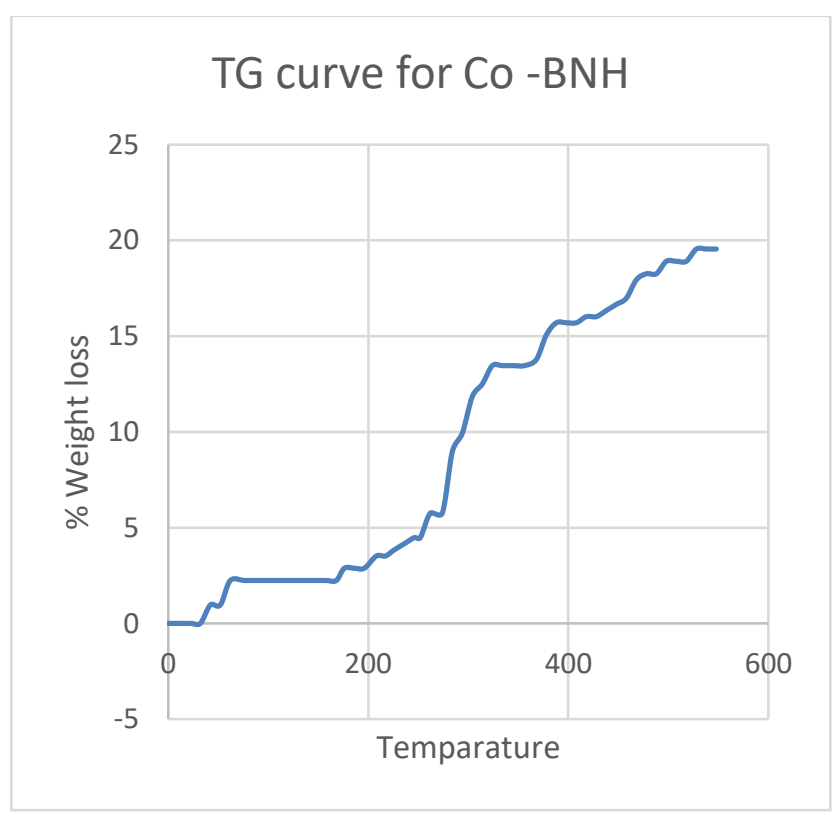

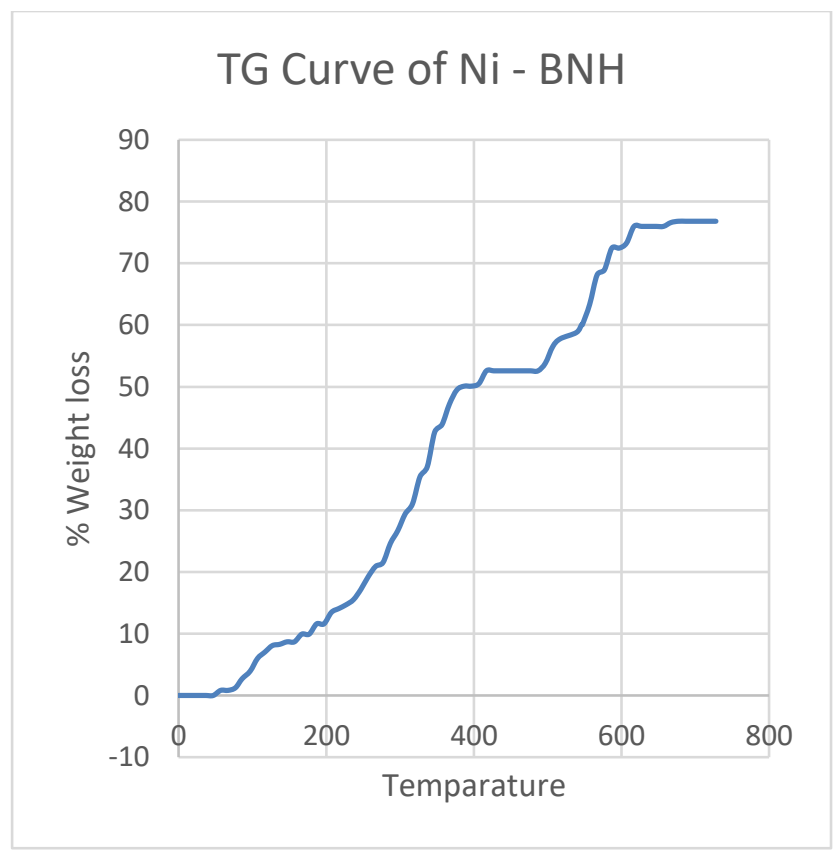



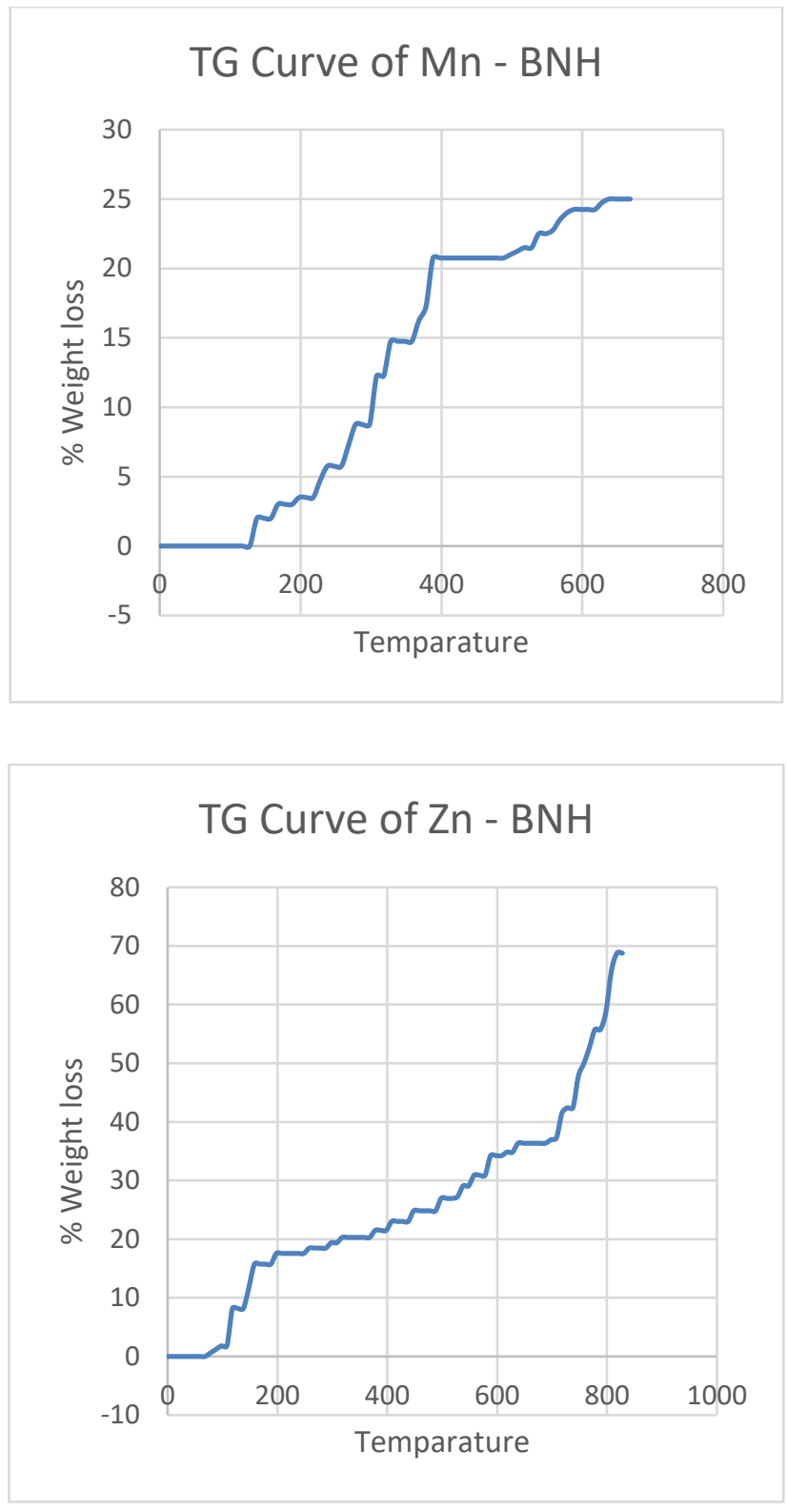

Antibacterial activity: All the compounds were screened in vitro for their antimicrobial activity against Escherichia coli by well diffusion method. The zone of inhibition values were found out at the end of $24 \mathrm{~h}$ at $37{ }^{\circ} \mathrm{C}$ for bacterial stains. The antibacterial data (Table- 2) (Fig. 1) suggested that Mannich base of piperidine and its complexes with zinc and cobalt metal were found to be biologically active. It is observed that activity of metal complexes of Mannich bases are good when compared with the ligand.
Table - 2 Antibacterial activity of ligand and its metal complexes

\begin{tabular}{|l|l|l|l|}
\hline Name & Compound & $\begin{array}{l}\text { Zone of } \\
\text { inhibition }\end{array}$ & $\begin{array}{l}\text { Anti } \\
\text { bacterial } \\
\text { activity }\end{array}$ \\
\hline Standard & Streptomycin & $12 \mathrm{~mm}$ & Active \\
\hline C & Zn- BNH & $5 \mathrm{~mm}$ & Active \\
\hline A & Mn- BNH & $0 \mathrm{~mm}$ & Inactive \\
\hline $\mathrm{D}$ & Ni- BNH & $0 \mathrm{~mm}$ & Inactive \\
\hline 4 & Co- BNH & $1.5 \mathrm{~mm}$ & Active \\
\hline 5 & BNH (Ligand) & $1 \mathrm{~mm}$ & Active \\
\hline
\end{tabular}
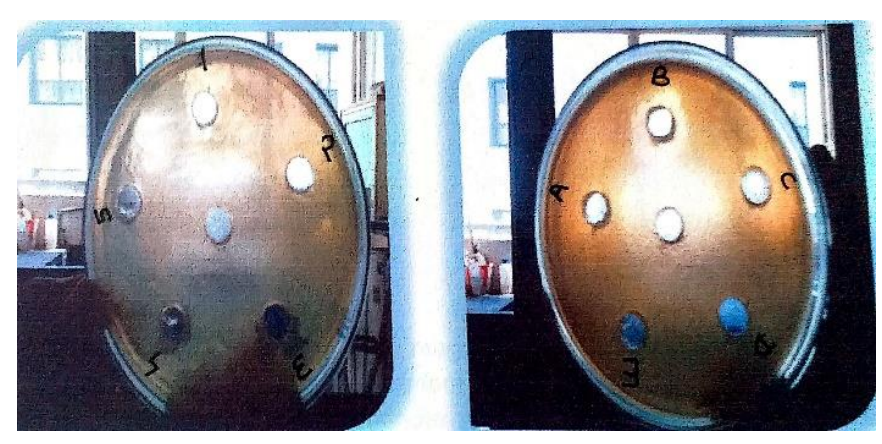

Figure 1: Zone of inhibition of antibacterial activity

\section{IV.CONCLUSION}

The ligand $\mathrm{BNH}$ and its metal complexes have been synthesized and characterized by IR and Thermogravimetry techniques. It is indicate from IR studies that the ligand is coordinated to metal as a bidentate ligand. The TG curve indicate the presence of two water molecules which are lattice water. The antibacterial screening of ligand shows inhibition in the growth of E.Coli. The metal complexes shows greater activity than the ligand.

\section{REFERENCES}

[1]. Dr. J. R. Shukla, International Journal of Scientific Research in Science and Technology (IJSRST), vol. 1, issue 1, 2015, pp 43-45. 
[2]. Benjamin List, J. American Chem. Soc., 122, Cite this article as : 38,2000, pp 9336-9337.

[3]. Najmodin Azizi et al, Org. Lett., 8, 10, 2006, pp 2079-2082.

[4]. Nabel A Negam et al, Bioorganic \& Medicinal Chemistry, Vol 13, issue 21, Nov 2005, pp 59215926.

[5]. M A Bhat et al, Applied Organometallic Chemistry, Vol 32, issue 5, May 2018, e4329.

Amol G. Kadlag, "Synthesis, Characterization and Antimicrobial Study of Mannich Base Derived from Piperidine and its Metal Complexes", International Journal of Scientific Research in Science and Technology (IJSRST), Online ISSN : 2395-602X, Print ISSN : 2395-6011, Volume 7 Issue 4, pp. 191-195, July-August 2020. Available at

[6]. K D Praliev et al, Pharmaceutical Chemistry Journal, 14, 1980, pp 620-622.

doi $\quad$ : https://doi.org/10.32628/IJSRST207457

Journal URL : http://ijsrst.com/IJSRST207457

[7]. V Gunasekaran et al, Asian J. Chem., 19, 116, 2007.

[8]. Ileana Dragutan et al, RSC Adv, 2, 2012, pp 719736.

[9]. Suvankar Das et al, Journal of Advanced Research, Vol 9, Jan 2018, pp 51-61.

[10]. Mauro Carcelli et al, Mol. Pharmaceutics, 11, 1, 2014, pp 304-316.

[11]. Sule Ceylan et al, Arch Pharm. Chem. Life Sci., Vol 346, issue 10, Oct 2013, pp 743-756.

[12]. Vijayta Gupta, Vinay Kant, Science International, 1 (7), 2013, pp 253-260.

[13]. Balasubramanian et al, Medicinal Chemistry Research, 21, 2012, pp 269-283.

[14]. S Sharma et al, Biomedicinal \& Pharmacotherapy, Vol 65, issue 4, July 2011, pp 244-251.

[15]. Nasser M et al, Journal of Chemistry, 2013, Article id 890617.

[16]. E Rodriguez et al, Journal of Inorganic Biochemistry, 99, 2005, pp 1558-1572.

[17]. N R Dhumane et al, Crystal Research \& Technology, 41, No 9, 2006, pp 897-901.

[18]. Hakan Arslan et al, Molecules, 14 (1), 2009, pp 519-527.

[19]. A Ashma et al, Asian Journal of Chemistry, Vol 29, No 11, 2017, pp 2501-2503. 